\title{
THE DETERMINANTS OF ADDING NON-PRODUCTION COSTS WHEN CALCULATING PRODUCT COSTS: EVIDENCE FROM THE SAUDI INDUSTRIAL SECTOR
}

\author{
Abdulrahman \\ Aljabr
}

\author{
School of Business, King Faisal University, Al-Hasaa, Saudi Arabia. \\ Email:aamaljabr@gmail.com
}

Article History

Received: 8 November 2021 Revised: 30 December 2021 Accepted: 17 January 2022 Published: 1 February 2022

\section{Keywords}

Cost system complexity Cost system design Importance of cost data Non-production costs Usage of cost data.

JEL Classification: M41.

\begin{abstract}
The quality of decision making and the level of performance are greatly affected by the accuracy of both production and non-production costs. While both components are important in increasing the accuracy of product costs in decision making, research into the inclusion of non-production costs is limited. Therefore, this research aims to examine the determinants of the addition of non-production costs when calculating product costs for use in decision making. This research utilized a questionnaire survey strategy to collect data from Saudi industrial operating units. The results of this research show that the level of cost data importance and its usage in decision making has no effect on adding non-production costs when calculating product costs, while the level of cost system complexity does. The results also add to the cost system design literature with regard to the addition of non-production costs when calculating product costs in the decision-making process.
\end{abstract}

Contribution/Originality: This research contributes to the cost system design literature by examining the influence of two important factors (the level of cost data importance and its use in decision making, and the level of cost system complexity) on the addition of total non-production costs rather than just the indirect component of these costs when calculating product costs for use in decision making.

\section{INTRODUCTION}

The accuracy of product costs is important in promoting informed decision making and optimal performance (Brierley, 2013; Ittner, Lanen, \& Larcker, 2002; Pizzini, 2006). To obtain more accurate product costs for decision making use, industrial operating units should account for the production costs (direct material, labor, and production overhead costs) and non-production costs (e.g., administrative, selling, and marketing costs) as they are both important components of total product costs (Drury \& Tayles, 1994; Johnson \& Loewe, 1987). Omitting any of these components can reduce the accuracy of product costs and, subsequently, performance (Kaplan, 1988; Kaplan \& Cooper, 1998). When calculating product costs for decision making use, operating units are assumed to include production costs as they represent an observable component of product costs. This assumption is also supported by the fact that production costs are required as part of product costs calculated for financial reporting purposes. However, operating units are inconsistent regarding the addition of non-production costs when calculating product costs for decision making use because most of these costs are not a clear component of product costs and are not allowed to be part of product costs calculated for financial reporting purposes (Brierley, 2017; Drury \& Tayles, 
1994; Lamminmaki \& Drury, 2001). This raises the question of what affects the addition of non-production costs when calculating product costs for decision making use. To the author's knowledge, only two studies have partially focused on the determinants of adding non-production costs when calculating product costs for decision making use (Brierley, 2015; Brierley, 2017). Despite the contributions of these studies, three research gaps remain.

The first research gap is the lack of focus on total non-production costs. The prior literature focused only on the indirect component of non-production costs (Brierley, 2015; Brierley, 2017). Including both direct and indirect non-production costs is important as each represents a considerable aspect of non-production costs and is related to the accuracy of product costs, and is therefore necessary to clearly understand the determinants of adding nonproduction costs when calculating product costs for decision making use (Drury \& Tayles, 1994; Johnson \& Loewe, 1987; Kaplan, 1988).

The second research gap is the lack of a quantitative examination of the effect of "the level of cost data importance and usage in decision making" on the addition of non-production costs when calculating product costs for decision making use. The importance and usage of cost data signals the level of dependence on cost data in decision making and, therefore, drives operating units to focus on the accuracy of cost data and, hence, assign both production and non-production costs to products (Brierley, Cowton, \& Drury, 2006; Charaf \& Bescos, 2013; Hoque, 2000; Ismail \& Mahmoud, 2012).

The third research gap is the lack of investigation into the link between cost system complexity (CSC) and the addition of non-production costs when calculating product costs for decision making use. This is surprising, given that the level of CSC reflects the level of complexity of the business and production environments, which affect the level of detail of the cost data and, therefore, the consideration of both production and non-production costs (Brierley, 2015).

Given (1) the importance of non-production costs in obtaining accurate product costs and achieving optimal performance; (2) the omission of focusing on total non-production costs; and (3) the lack of consideration of the effect of both the level of cost data importance and usage in decision making and the level of CSC on the addition of total non-production costs, this paper aims to test the influence of the level of cost data importance and usage in decision making and the level of CSC on adding non-production costs when calculating product costs for decision making use.

The remaining sections include a literature review and development of propositions section (Section 2), a research methodology and methods section (Section 3), a results section (Section 4) and a discussion and conclusion section (Section 5).

\section{LITERATURE REVIEW AND RESEARCH PROPOSITIONS}

Since introducing activity-based costing (ABC) in the 1980 s as an improved methodology to assign indirect costs, including the elements of indirect production and non-production costs to products and, hence, to produce more accurate costs for decision making use (Cooper, 1988a; Cooper, 1988b; Cooper, 1989a; Cooper, 1989b), a considerable amount of research has been published to examine the determinants and consequences of ABC (AlSayed \& Dugdale, 2016; Aljabr, 2020; Alsayegh, 2020; Hadid, 2019; Malmi, 1999; Rankin, 2020). This line of research has provided valuable insights regarding the nature of the effect of various factors, such as competition (Malmi, 1999; Nguyen \& Brooks, 1997), production complexity (Aljabr, 2020; Schoute, 2011), the level of indirect costs (Cohen, Venieris, \& Kaimenaki, 2005; Jusoh \& Miryazdi, 2015) and strategy (Gosselin, 1997; Hadid, 2019), on the adoption of ABC. It has also provided insights about the outcomes of ABC adoption (Vetchagool, Augustyn, \& Tayles, 2020). Collectively, this line of research has helped to enhance our knowledge in relation to situations in which ABC is worth the investment (Aljabr, 2020; Kaplan \& Cooper, 1998; Stuart, 2013).

In the early 2000s, the research into $\mathrm{ABC}$ adoption was extended to cover not only $\mathrm{ABC}$, but also the level of CSC (Abernethy, Lillis, Brownell, \& Carter, 2001; Moalla \& Mezouel, 2020; Moalla \& Basti, 2020; Schoute, 2009; 
Schoute \& Budding, 2017b; Schoute \& Budding, 2017a). This line of research has contributed towards improving our understanding of CSD by providing insights regarding the determents and consequences of CSC, a concept that covers both traditional cost systems and ABC (Al-Omiri \& Drury, 2007).

The literature review identified two studies that partially address the issue of interest to this research, namely the determinants of the addition of non-production costs when calculating product costs for decision making use (Brierley, 2015; Brierley, 2017). Brierley (2015) adopted a quantitative approach using a questionnaire to examine the determinants of adding non-production costs when calculating product costs. Unexpectedly, the study found that the percentage of these costs negatively affects their inclusion in product costs. In addition, the study found no support for the effect of competition, customization, the effect of the financial accounting requirements on product costing and operating unit size. Brierley (2017) adopted a qualitative approach using interviews and found that the main reasons for adding non-production overhead costs when calculating product costs were to account for them in pricing decisions, to calculate the relevant product costs for various decisions, and to recover them to avoid losses. In addition, the study reported that the main reasons for excluding these costs were the impact of the parent company, and the view that these costs are either irrelevant for decision making or difficult to assign to products accurately.

As mentioned in Section 1, no study has considered the direct component of non-production costs along with the indirect component, even though the former represents a critical part of product costs that contributes towards its accuracy (Kaplan \& Cooper, 1998). In addition, no quantitative study has accounted for the effect of the level of cost data importance and usage that reflects the extent of the reliance on cost data when making decisions and, subsequently, affects the addition of both production and non-production costs when calculating product costs. The qualitative results reported by Brierley (2017) provided evidence of the link between the level of cost data importance and usage in decision making and the addition of the indirect component of non-production costs when calculating product costs for decision making use.

Furthermore, the effect of CSC on the addition of total non-production costs when calculating product costs for decision making use has been neglected, despite the fact that the level of CSC indicates the level of complexity of the business and production environments that impact the amount of detail of the cost data and, subsequently, the addition of both production and non-production costs (Brierley, 2015). In particular, high levels of CSC reflect high complex business and production environments that require detailed product costs, which should cover both production and non-production costs, in order for businesses to be in a position to compete and succeed (Drury \& Tayles, 2005).

Given the above, this paper will test the following propositions:

Proposition 1: The level of cost data importance and usage in decision making is positively related to the addition of total non-production costs when calculating product costs for decision making use.

Proposition 2: The level of CSC is positively related to the addition of total non-production costs when calculating product costs for decision making use.

\section{RESEARCH METHODOLOGY AND METHODS}

A questionnaire was utilized to achieve the research aim, which is to examine the determinants of adding nonproduction costs when calculating product costs for decision making use. This method enables the collection of quantitative data from a large number of participants and analysis of the data using suitable statistical analysis techniques. The questionnaire is composed of tailored questions to collect reliable responses regarding the research constructs. To enhance the quality and number of responses, the questionnaire was constructed and administrated using the guidelines suggested by Dillman, Smyth, \& Christian (2014). The data were collected from industrial operating units operating in Saudi Arabia. The industrial sector was chosen because it incorporates both production and non-production costs, which makes it possible to test the determinants of adding the latter costs. Saudi Arabia 
was deemed a suitable research context because the country has been experiencing developments in its business and production environments that are likely to impact the cost system design (CSD) and the inclusion of both production and non-production costs in product costs (Vision 2030, 2018; World Trade Organization (WTO), $2021)$.

Together, the Saudi Industrial Property Authority (MODON) and the Royal Commission for Jubail and Yanbu (RCJY) databases were used as sample frames since they include the most up-to-date and comprehensive information about Saudi industrial operating units. MODON covers all Saudi industrial cities, except for Jubail and Yanbu, which are the only industrial cities covered by RCJY. The questionnaire was distributed to only 368 operating units due to the fact that not all of the required details were present in the databases, which necessitated making initial contact via either visits or phone calls. Although the administration process reduced the sample size to save time and cost, it enhanced the accuracy of the data and results because it made it possible to target the person responsible for the assignment of indirect costs to products who was also knowledgeable about the operating unit. Multiple reminders were sent to non-respondents. A total of 200 (54.3\%) questionnaires were returned without any issues regarding missing or inconsistent data or outliers (Hair, Hult, Ringle, \& Sarstedt, 2017; Tabachnick \& Fidell, 2007). A non-response bias analysis that involved comparing early respondents $(\mathrm{N}=120)$ with late ones $(\mathrm{N}=80)$ revealed no significant differences between the two groups in relation to the level of cost data importance and usage in decision making and the level of CSC, which suggests no effect of this bias on the results of this research (Armstrong \& Overton, 1977; Van der Stede, Young, \& Chen, 2005).

The level of cost data importance and usage in decision making (Importance-USAGE) was measured by adding the mean value of two separate constructs, one for the extent of importance and the second for the extent of usage, adapted from Brierley et al. (2006) and Schoute (2009). Each construct involved nine items related to various decisions, each measured by the responses to a five-point Likert-scale question. A zero point response option was included to indicate non-usage of the decision. The mean values for the two constructs was calculated based on the used decisions. The level of CSC was measured by a composite score of the number of cost pools and drivers (CSCComposite) (Drury \& Tayles, 2005; Schoute, 2009). The addition of total non-production costs was measured by a dichotomous measure of adding versus not adding total non-production costs when calculating product costs for decision making use (Non-Production) (Brierley, 2015). All of the constructs involved in this research are singleitem constructs and, accordingly, have a relationship of " 1 " with their single indicator, meaning that the constructs and indicators have identical values (Hair et al., 2017). For such constructs, no measurement evaluation is needed (ibid).

\section{RESULTS}

\subsection{Descriptive Analysis}

Table 1 shows that $74.50 \%(n=149)$ of the operating units add non-production costs when calculating product costs for decision making use, while $25.50 \%(n=51)$ do not. This indicates that the majority of operating units consider non-production costs as an important component of product costs and, hence, add them when calculating product costs for decision making use. The percentage of operating units that add non-production costs reported in this research $(74.50 \%)$ is higher than that reported by Brierley (2015) (61.50\%). Table 2 presents the descriptive information for the determinants of Importance-Usage and CSC-Composite. The results show that the level of Importance-Usage (mean $=7.89$, median $=7.89$, theoretical range: 1 to 10 ) is high, suggesting that operating units consider product cost data to be very important for decision making and use it extensively in when making decisions. However, the results showed that the level of CSC-Composite (mean $=5.85$, median $=6$, theoretical range: 0 to 15 ) is low, indicating that Saudi industrial operating units operate with less complex cost systems. 
Table 1. Operating units' addition of non-production costs.

\begin{tabular}{c|c|c}
\hline $\begin{array}{l}\text { Addition of non-production costs } \\
\text { when calculating product costs }\end{array}$ & $\mathbf{N}$ & $\mathbf{\%}$ \\
\hline No & 51 & 25.50 \\
\hline Yes & 149 & 74.50 \\
\hline Total & 200 & 100.00 \\
\hline
\end{tabular}

Table 2. Descriptive statistics for the research constructs.

\begin{tabular}{l|c|c|c|c}
\hline Construct & Mean & Std. Deviation & Minimum & Maximum \\
\hline Importance-Usage & 7.89 & 1.19 & 3.33 & 10.00 \\
\hline Composite & 5.85 & 3.45 & 0.00 & 15.00 \\
\hline
\end{tabular}

Table 3 shows the Pearson correlations between the independent and dependent constructs. The results provide initial support for the effect of CSC-Composite on Non-Production as the correlation between the two is positive and significant, but they do not do so for the impact of Importance-Usage on Non-Production, as the correlation between the two is insignificant. The results also show a significant positive correlation between Importance-Usage and CSC-Composite, but it is small and does not raise a multicollinearity issue (Pallant, 2013).

Table 3. The Pearson correlations of all constructs.

\begin{tabular}{l|c|c|c}
\hline & Importance-Usage & CSC-Composite & Non-Production \\
\hline Importance-Usage & 1.00 & $0.15^{*}$ & 0.07 \\
\hline CSC-Composite & $0.15^{*}$ & 1.00 & $0.17^{*}$ \\
\hline Non-Production & 0.07 & $0.17^{*}$ & 1.00 \\
\hline Note: ${ }^{*}$ Correlation is significant at the 0.05 level (2-tailed).
\end{tabular}

\subsection{Proposition Testing}

Given that the dependent variable of Non-Production is a dichotomous variable, logistic regression analysis was used as it is the most appropriate statistical analysis method for dichotomous dependent variables that include two categories (Field, 2013; Hair, Black, Babin, \& Anderson, 2019; Pallant, 2013). The method allows the use of both categorical and continuous predictors (i.e., independent variables) and can be applied after meeting assumptions related to sample size, multicollinearity and outliers (Pallant, 2013). In this research, the logistic regression model involved regressing Non-Production on Importance-Usage and CSC-Composite. Table 4 provides the results for the tested logistic model. ${ }^{1}$ The results show that the model is significant, as indicated by the significance value of the Chi-square goodness of fit test (Chi-square $=6.22, \mathrm{p}<0.05)$. In addition, the results show that the Hosmer and Lemeshow goodness-of-fit statistic is not significant (6.51, p > 0.05), indicating a good model fit. Both results mean that the model was able to differentiate between operating units that add and do not add total non-production costs when calculating product costs. However, the amount of variation explained in nonProduction is low (0.03 to 0.05), as indicated by the low Cox and Snell R squared and Nagelkerke R squared values. This indicates that other variables exist that affect non-Production that are not included in the model. In relation to the effect of Importance-Usage and CSC-Composite, the results agree with those of the correlation analysis, as only CSC-Composite was found to have a positive significant influence on Non-Production $(B=0.12, \mathrm{p}<0.05)$.

\footnotetext{
${ }^{1}$ The assumptions of the logistic regression analysis was met as the sample size was large enough (200 cases). The issue regarding outliers was resolved by removing multivariate outliers, and no issue was observed in relation to multicollinearity.
} 
Asian Economic and Financial Review, 2022, 12(2): 89-98

Table 4. Results of the logistic regression model of the determinants of non-production.

\begin{tabular}{|c|c|c|c|c|c|c|c|c|c|c|}
\hline & $\begin{array}{c}\text { B } \\
\text { (Coefficient) }\end{array}$ & $\begin{array}{l}\text { Standard } \\
\text { error }\end{array}$ & Wald & $\begin{array}{l}\text { Degree of } \\
\text { freedom }\end{array}$ & Sig. & $\operatorname{Exp}(B)$ & $\begin{array}{c}\text { Chi-square } \\
\text { (sig.) }\end{array}$ & $\begin{array}{c}\text { Hosmer and } \\
\text { Lemeshow (sig.) }\end{array}$ & $\begin{array}{c}\text { Cox \& Snell } \\
\text { R Squared }\end{array}$ & $\begin{array}{c}\text { Nagelkerke } \\
\text { R Squared }\end{array}$ \\
\hline Importance-Usage & 0.09 & 0.14 & 0.39 & 1.00 & 0.53 & 1.09 & $6.22(0.045)$ & $6.51(0.59)$ & 0.03 & 0.05 \\
\hline CSC-Composite & 0.12 & 0.05 & 4.87 & 1.00 & 0.03 & 1.12 & & & & \\
\hline Constant & -0.23 & 1.07 & 0.05 & 1.00 & 0.83 & 0.80 & & & & \\
\hline
\end{tabular}




\section{DISCUSSION AND CONCLUSION}

This paper aimed to test the effect of the level of cost data importance and usage in decision making (Importance-Usage) and the level of CSC (CSC-Composite) on the addition of total non-production costs when calculating product costs for decision making use (Non-Production). The paper is motivated by the importance of non-production costs in obtaining accurate product costs and achieving optimal performance, the omission of focusing on total non-production costs despite the importance of both the direct and indirect components of these costs, and the lack of consideration of the effect of both Importance-Usage and CSC-Composite on Non-Production, although the former factors encourage the addition of the latter when calculating product costs. Using questionnaire data obtained from the Saudi industrial sector, the results showed that Importance-Usage does not influence Non-Production, while CSC-Composite does.

The insignificant impact of Importance-Usage is surprising, given that the factor indicates the extent to which the operating unit relies on cost data in decision making and hence requires accurate product cost data that typically includes both production and non-production costs (Al-Omiri \& Drury, 2007; Brierley et al., 2006; Hoque, 2000). The results do not support Proposition 1 and are in contrast to the qualitative findings of Brierley (2017), which showed a link between the level of cost data importance and usage and the addition of the indirect component of non-production costs in product costs. The insignificant results can be attributed to the fact that, although cost data is important and is used in decision making, non-production costs are not added due to the effect of the parent company and the presumed irrelevance of these costs for decision making or the lack of knowledge or resources to assign them to product costs accurately (Brierley, 2017). In addition, it is possible that a large proportion of Saudi operating units utilize the short-term perspective on calculating product costs for decision making use, which excludes most of the indirect components of production and non-production costs (Drury \& Tayles, 2000, 2006). This is in contrast to the long-term perspective, which incorporates the avoidable part of indirect production and non-production costs advocated by ABC proponents (Kaplan, 1990; Labro, 2019). The utilization of the short-term perspective in calculating product costs for decision making use might be attributed to the fact that it is a widely taught perspective in most textbooks (Kaplan, 1990).

The significant effect of CSC-Composite on Non-Production conforms to the expectations indicated in Proposition 2, as higher levels of CSC-Composite are associated with higher levels of Non-Production. This effect supports the argument that CSC mirrors the extent of the complexity of the business and production environments that influence the level of detail of cost data and, hence, the addition of both production and non-production costs. These results, however, conflict with those of Brierley (2015), who found no support for the positive impact of multiple factors that represent surrogates to the business and production environments on Non-Production. This could be due to differences in the research context and the measure used for Non-Production.

This paper is not without limitations, meaning that there are future research opportunities. First, this research measured Non-Production as a dichotomous variable, although the extent of adding non-production costs can vary greatly between different operating units. Hence, future research should utilize continuous measures for NonProduction to capture the differences in practice regarding the addition of these costs when calculating product costs for decision making use. Second, this research assumed that the level of CSC is likely to reflect the business and production environments and the amount of detail required in cost data, although there is evidence that the design of the cost system does not always reflect the requirements of the business and production environments (Hiromoto, 1988; Merchant \& Shields, 1993). Accordingly, future research should, in addition to considering CSC, account for factors, such as production complexity and competition, that reflect the business and production environments when testing for the determinants of Non-Production. Third, despite the suitability of the research strategy, namely a questionnaire survey, to achieve the research aim, it only offers limited interaction between the researcher and the participants. Therefore, future research can rely on field-based research to obtain a deeper understanding of the practices and determinants of Non-Production (Modell, 2005). Notwithstanding these 
limitations, this paper contributes to the cost system design literature by examining the impact of the level of cost data importance and usage in decision making and the level of cost system complexity on the addition of total nonproduction costs when calculating product costs for decision making use.

Funding: The author acknowledges the Deanship of Scientific Research at King Faisal University for the financial support under Nasher Track (Grant number: 186159).

Competing Interests: The author declares that there are no conflicts of interests regarding the publication of this paper.

\section{REFERENCES}

Abernethy, M. A., Lillis, A. M., Brownell, P., \& Carter, P. (2001). Product diversity and costing system design choice: Field study evidence. Management Accounting Research, 12(3), 261-279. Available at: https://doi.org/10.1006/mare.2001.0168.

Al-Omiri, M., \& Drury, C. (2007). A survey of factors influencing the choice of product costing systems in UK organizations. Management Accounting Research, 18(4), 399-424. Available at: https://doi.org/10.1016/j.mar.2007.02.002.

Al-Sayed, M., \& Dugdale, D. (2016). Activity-based innovations in the UK manufacturing sector: Extent, adoption process patterns and contingency factors. The British Accounting Review, 48(1), 38-58. Available at: https://doi.org/10.1016/j.bar.2015.03.004.

Aljabr, A. (2020). The influences on activity-based costing adoption as an optimal costing system design: Evidence from Saudi Arabia. Journal of Accounting and Management Information Systems, 19(3), 444-479. Available at: https://doi.org/10.24818/jamis.2020.01002.

Alsayegh, M. F. (2020). Activity based costing around the world: Adoption, implementation, outcomes and criticism. Journal of Accounting and Finance in Emerging Economies, 6(1), 25 1-262. Available at: https://doi.org/10.26710/jafee.v6i1.1074.

Armstrong, J. S., \& Overton, T. S. (1977). Estimating nonresponse bias in mail surveys. Journal of Marketing Research, 14(3), 396402. Available at: https://doi.org/10.1177/002224377701400320.

Brierley, J. A. (2013). The uses of product costs in decision-making. International Journal of Managerial and Financial Accounting, 5(3), 294-309. Available at: https://doi.org/10.1504/ijmfa.2013.058551.

Brierley, J. A. (2015). An examination of the factors influencing the inclusion of non-manufacturing overhead costs in product costs. International Journal of Managerial and Financial Accounting, 7(2), 134-150. Available at: https://doi.org/10.1504/ijmfa.2015.071195.

Brierley, J. (2017). Identifying the influences on the inclusion of non-manufacturing overhead costs in product costs. Advances in Business and Management, 11, 141-158.

Brierley, J. A., Cowton, C. J., \& Drury, C. (2006). A note on the importance of product costs in decision-making. Advances in Management Accounting, 15, 249-265. Available at: https://doi.org/10.1016/s1474-7871(06)15011-x.

Charaf, K., \& Bescos, P.-L. (2013). The role of organizational and cultural factors in the adoption of activity-based costing: The case of Moroccan firms. Journal of Accounting and Management Information Systems, 12(1), 4-2 1.

Cohen, S., Venieris, G., \& Kaimenaki, E. (2005). ABC: Adopters, supporters, deniers and unawares. Managerial Auditing Journal, 20(9), 981-1000. Available at: https://doi.org/10.1108/02686900510625325.

Cooper, R. (1988a). Cost management concepts and principles: The rise of activity based costing-part one what is an activity based cost system. Journal of Cost management, 2(1), 45-54.

Cooper, R. (1988b). The rise of activity-based costing — part two: When do I need an activity-based cost system? Journal of Cost Management for the Manufacturing Industry, 2(Fall), 41-48.

Cooper, R. (1989a). The rise of activity-based costing — part four: What do activity-based cost systems look like? Journal of Cost Management for the Manufacturing Industry, 3(Spring), 38-49.

Cooper, R. (1989b). The rise of activity-based costing — part three: How many cost drivers do you need, and how do you select them? Journal of Cost Management for the Manufacturing Industry, 3(Winter), 34-46. 
Dillman, D. A., Smyth, J. D., \& Christian, L. M. (2014). Internet, phone, mail, and mixed-mode surveys: The tailored design method. New Jersey, USA: John Wiley \& Sons, Inc.

Drury, C., \& Tayles, M. (1994). Product costing in UK manufacturing organizations. European Accounting Review, 3(3), 443-470. Available at: https://doi.org/10.1080/09638189400000031.

Drury, C., \& Tayles, M. (2000). Cost system design and profitability analysis in UK companies. London, UK: The Chartered Institute of Management Accountants.

Drury, C., \& Tayles, M. (2005). Explicating the design of overhead absorption procedures in UK organizations. The British Accounting Review, 37(1), 47-84. Available at: https://doi.org/10.1016/j.bar.2004.08.003.

Drury, C., \& Tayles, M. (2006). Profitability analysis in UK organizations: An exploratory study. The British Accounting Reviere, 38(4), 405-425. Available at: https://doi.org/10.1016/j.bar.2006.05.003.

Field, A. (2013). Discovering statistics using IBM SPSS statistics. London, UK: Sage Publications Ltd.

Gosselin, M. (1997). The effect of strategy and organizational structure on the adoption and implementation of activity-based costing. Accounting, Organizations and Society, 22(2), 105-122. Available at: https://doi.org/10.1016/s03613682(96)00031-1.

Hadid, W. (2019). Lean service, business strategy and ABC and their impact on firm performance. Production Planning $\mathcal{E}^{\circ}$ Control, 30(14), 1203-1217. Available at: https://doi.org/10.1080/09537287.2019.1599146.

Hair, J. F., Hult, G. T. M., Ringle, C. M., \& Sarstedt, M. (2017). A primer on partial least squares structural equation modeling (PLSSEM). California, USA: Sage Publications, Inc.

Hair, J., Black, W., Babin, B., \& Anderson, R. (2019). Multivariate data analysis. Andover, UK: Cengage Learning EMEA.

Hiromoto, T. (1988). Another hidden edge-Japanese management accounting. Harvard Buisiness Revierw, 66(4), 22-26.

Hoque, Z. (2000). Just-in-time production, automation, cost allocation practices and importance of cost information: An empirical investigation in New Zealand-based manufacturing organizations. The British Accounting Revierw, 32(2), 133-159. Available at: https://doi.org/10.1006/bare.1999.0125.

Ismail, T. H., \& Mahmoud, N. (2012). The influence of organizational and environmental factors on cost systems design in Egypt. British Journal of Economics, Finance and Management Sciences, 4(2), 31-51.

Ittner, C. D., Lanen, W. N., \& Larcker, D. F. (2002). The association between activity-based costing and manufacturing performance. Journal of Accounting Research, 4O(3), 71 1-726. Available at: https://doi.org/10.1 111/1475-679x.00068.

Johnson, H. T., \& Loewe, D. A. (1987). How weyerhaeuser manages corporate overhead costs [2]. Strategic Finance, 69(2), 20.

Jusoh, R., \& Miryazdi, S. (2015). The influence of technological and environmental factors on the diffusion of activity-based costing in Iran. TÉKHNE - Review of Applied Management Studies, 13(2), 95-109. Available at: https://doi.org/10.1016/j.tekhne.2015.12.001.

Kaplan, R. S. (1988). One cost system isn't enough (pp. 61-66): Harvard Business Review.

Kaplan, R. S., \& Cooper, R. (1998). Cost \& effect: Using integrated cost systems to drive profitability and performance. Massachusetts, USA: Harvard Business School Press.

Kaplan, R. S. (1990). Contribution margin analysis: No longer relevant/strategic cost management: The new paradigm. Journal of Management Accounting Research, 2, 2-15.

Labro, E. (2019). Costing systems. Massachusetts: USA Now Publishers Inc.

Lamminmaki, D., \& Drury, C. (2001). A comparison of New Zealand and British product-costing practices. The International Journal of Accounting, 36(3), 329-347. Available at: https://doi.org/10.1016/s0020-7063(01)00106-6.

Malmi, T. (1999). Activity-based costing diffusion across organizations: An exploratory empirical analysis of Finnish firms. Accounting, Organizations and Society, 24(8), 649-672. Available at: https://doi.org/10.1016/s0361-3682(99)00011-2.

Merchant, K. A., \& Shields, M. D. (1993). When and why to measure costs less accurately to improve decision making. Accounting Horizons, 7(2), 76-81. 
Moalla, H., \& Mezouel, A. (2020). The impact of contingency factors on the sophistication of costing systems: Evidence from Tunisia. Journal of Accounting, Business and Management, 27(2), 84-100. Available at: https://doi.org/10.31966/jabminternational.v27i2.702.

Moalla, H., \& Basti, C. (2020). The influence of internal actors on the sophistication of costing systems in Tunisia. Asia-Pacific Management Accounting Journal, 15(3), 1-23. Available at: https://doi.org/10.24191/apmaj.v 15i3-01.

Modell, S. (2005). Triangulation between case study and survey methods in management accounting research: An assessment of validity implications. Management Accounting Research, 16(2), 231-254. Available at: https://doi.org/10.1016/j.mar.2005.03.001.

Nguyen, H. V., \& Brooks, A. (1997). An empirical investigation of adoption issues relating to activity-based costing. Asian Review of Accounting, 5(1), 1-18. Available at: https://doi.org/10.1108/eb060679.

Pallant, J. (2013). SPSS survival manual. Maidenhead, UK: Open University Press, McGraw-Hill Education.

Pizzini, M. J. (2006). The relation between cost-system design, managers' evaluations of the relevance and usefulness of cost data, and financial performance: an empirical study of US hospitals. Accounting, Organizations and Society, 31(2), 179210. Available at: https://doi.org/10.1016/j.aos.2004.11.001.

Rankin, R. (2020). The predictive impact of contextual factors on activity-based costing adoption. Journal of Accounting and Finance, 20(1), 66-81. Available at: https://doi.org/10.33423/jaf.v20i1.2742.

Schoute, M. (2009). The relationship between cost system complexity, purposes of use, and cost system effectiveness. The British Accounting Reviere, 41(4), 208-226. Available at: https://doi.org/10.1016/j.bar.2009.10.001.

Schoute, M. (2011). The relationship between product diversity, usage of advanced manufacturing technologies and activitybased costing adoption. The British Accounting Review, 43(2), 120-134. Available at: https://doi.org/10.1016/j.bar.2011.02.002.

Schoute, M., \& Budding, T. (2017b). Stakeholders' information needs, cost system design, and cost system effectiveness in Dutch local government. Financial Accountability \& Management, 33(1), 77-101. Available at: https://doi.org/10.1111/faam.12116.

Schoute, M., \& Budding, T. (2017a). Changes in cost system design and intensity of use in times of crisis: Evidence from Dutch local government. Advances in Management Accounting, 29(Chapter 1), 1-31. Available at: https://doi.org/10.1108/S1474-787120170000029004.

Stuart, N. V. (2013). Assessing the costs and benefits of investing in cost system accuracy. Journal of Corporate Accounting E Finance, 25(1), 59-68. Available at: https://doi.org/10.1002/jcaf.21909.

Tabachnick, B. G., \& Fidell, L. S. (2007). Using multivariate statistics. Massachusetts,USA: Pearson Education, Inc.

Van der Stede, W. A., Young, S. M., \& Chen, C. X. (2005). Assessing the quality of evidence in empirical management accounting research: The case of survey studies. Accounting, Organizations and Society, 30(7-8), 655-684. Available at: https://doi.org/10.1016/j.aos.2005.01.003.

Vetchagool, W., Augustyn, M. M., \& Tayles, M. (2020). Impacts of activity-based costing on organizational performance: Evidence from Thailand. Asian Review of Accounting, 28(3), 329-349. Available at: https://doi.org/10.1108/ara-082018-0159.

Vision 2030. (2018). National industrial development \& logistics program (Delivery Plan 2018-2020). Riyadh, Saudi Arabia: Vision 2030.

World Trade Organization (WTO). (2021). Member information: Kingdom of Saudi Arabia. Retrieved from http://www.wto.org/english/thewto e/countries e/saudi arabia e.htm.

Views and opinions expressed in this article are the views and opinions of the author. Asian Economic and Financial Review shall not be responsible or answerable for any loss, damage or liability caused in relation to/arising from the use of the content. 